\title{
DIREITO E BARBÁRIE NA CONQUISTA DA AMÉRICA INDÍGENA
}

\section{Lucas Borges de Carvalho}

Mestrando em Teoria e Filosofia do Direito pela UFSC - Universidade Federal de Santa Catarina. Bolsista da CAPES.

e-mail: lucasbcarvalho@terra.com.br.

Agradeço ao Prof. Antônio Carlos Wolkmer pelo incentivo à elaboração e ampliação deste artigo, que, originalmente, foi apresentado como trabalho de conclusão da disciplina História das Instituições Jurídicas, por ele ministrada no CPGD/UFSC no segundo trimestre de 2004.

RESUMO: $O$ artigo analisa alguns aspectos da conquista da América Espanhola, particularmente, o massacre dos índios, a luta política do frade dominicano Bartolomé de Las Casas, os debates em torno da guerra justa, bem como a legislação promulgada à época, ora protegendo os indígenas, ora chancelando a opressão dos conquistadores. A partir desses fatos históricos, procura-se demonstrar como as raízes do processo de negação do outro e de desrespeito à diversidade, tal como se configuram na era moderna, podem ser encontradas no período da Conquista.

PALAVRAS-CHAVE: Conquista. América Espanhola. Bartolomé de Las Casas. 


\section{INTRODUÇÃO}

O objetivo deste trabalho é analisar, ainda que brevemente, alguns aspectos da conquista da América espanhola. Trata-se de, numa perspectiva crítica, resgatar episódios como o massacre dos índios, os debates em torno da guerra justa, bem como a atuação do frade dominicano Bartolomé de Las Casas na defesa e proteção dos indígenas.

Além disso, busca-se situar a legislação que regulamentou a colonização espanhola, ora no sentido de proteção dos ameríndios, ora no sentido de permitir a barbárie então realizada. De antemão, é importante deixar claro que as leis de proteção aos índios foram de pouca valia diante do total desrespeito ao outro e da ganância dos encomendeiros por ouro e outras riquezas.

Mas, por que estudar episódios tão longínquos? Ora, o processo de colonização inaugura a era moderna: os espanhóis levam a fé cristã, mas em troca, não querem status ou glórias típicas dos senhores e guerreiros da Idade Média. É o desejo de enriquecer, através da exploração do outro e do ouro, que marca toda a conquista. O dinheiro é, desde então, um valor que se sobrepõe aos demais. Em nome dele, tudo, absolutamente tudo, será permitido.

Daí a atualidade do tema: buscar nos primórdios da modernidade, as raízes das barbáries do século XXI. Assim como os colonizadores, o imperialismo fundamentalista contemporâneo declarou, desrespeitando todos os preceitos e instituições de direito internacional, uma "guerra justa" contra outros Estados a fim de levar aos "povos bárbaros" a fé nos "valores universais" da democracia e da liberdade.

O nosso tempo é fruto direto daquele remoto passado. Os elementos que então surgiam, afirmaram-se numa magnitude que jamais os homens da época poderiam imaginar. Olhar para trás, portanto, significa, nada mais nada menos do que olhar para nós mesmos.

\section{O PARAíSO DESTRUÍDO: O MASSACRE NA AMÉRICA INDÍGENA}

As guerras, a escravidão, os maus-tratos, os assassinatos em massa, a catequização e a difusão de doenças como varíola e rubéola foram os principais 
mecanismos utilizados no massacre dos indígenas. Calcula-se que tenham morrido 70 milhões de ameríndios em aproximadamente um século. Só no México, no mesmo período, foram mortos 24 milhões de pessoas, uma das maiores hecatombes da história da humanidade. ${ }^{1}$

Não à toa, portanto, os conquistadores espanhóis ficaram conhecidos pela ferocidade e crueldade com que assassinavam e subjugavam os índios. A partir dos poucos registros existentes, pode-se vislumbrar a dimensão da barbárie realizada. $A$ respeito, veja-se, por todos, o seguinte relato de Las Casas²:

Os espanhóis, com seus cavalos, suas espadas e lanças começaram a praticar crueldades estranhas; entravam nas vilas, burgos e aldeias, não poupando nem as crianças e os homens velhos, nem as mulheres grávidas e parturientes e lhes abriam o ventre e as faziam em pedaços como se estivessem golpeando cordeiros fechados em seu redil. Faziam apostas sobre quem, de um só golpe de espada, fenderia e abriria um homem pela metade, ou quem, mais habilmente e mais destramente, de um só golpe lhe cortaria a cabeça, ou ainda sobre quem abriria as entranhas de um homem de um só golpe. Arrancavam os filhos dos seios da mãe e Ihes esfregavam a cabeça contra os rochedos [...] Faziam certas forcas longas e baixas, de modo que os pés tocavam quase a terra, um para cada treze, em honra e reverência de Nosso Senhor e de seus doze Apóstolos (como diziam) e deitando-lhes fogo, queimavam vivos todos os que ali estavam presos. Outros, a quem quiseram deixar vivos, cortaram-Ihes as duas mãos e assim os deixavam.

Essa brutal carnificina é decorrência direta de uma época na qual antigas justificativas religiosas da desigualdade entre os seres humanos conjugaram-se ao nascente desejo desenfreado de enriquecer dos europeus. Conforme aponta Tzevtan Todorov, os conquistadores espanhóis pertencem, historicamente, a um período de transição "entre uma Idade Média dominada pela religião e a época moderna, que coloca os bens materiais no topo de sua escala de valores". ${ }^{3} \mathrm{~A}$ conquista, na prática, foi marcada por esses dois aspectos: os cristãos vêm ao Novo Mundo imbuídos de religião e levam, em troca, metais preciosos e riquezas.

\footnotetext{
1 Sobre as estimativas de mortos no decorrer da conquista espanhola, ver TODOROV, Tzvetan. A conquista da América: a questão do outro. 2 $2^{\underline{a}}$ ed. São Paulo: Martins Fontes, 1988, p. 129; BRUIT, Héctor Hernan. Bartolomé de Las Casas e a simulação dos vencidos. Campinas: Unicamp, 1995, p. 43-44.

${ }^{2}$ LAS CASAS, Bartolomé de. 0 paraíso destruído: brevíssima relação da destruição das Índias. $6^{\underline{a}}$ ed. Porto Alegre: L\&PM, 1996, p. 30. Sobre o genocídio na América Espanhola, ver LEÓN-PORTILLA, Miguel. A visão dos vencidos: a tragédia da conquista narrada pelos astecas. Tradução: Carlos Urbin e Jacques Wainberg. Porto Alegre: L\&PM, 1985.
}

${ }^{3}$ TODOROV, T. op. cit., p. 40. 
O mesmo autor acentua que o desejo de enriquecer e a paixão pelo ouro nada têm de especificamente modernos. ${ }^{4} \mathrm{O}$ que marca e torna peculiar a era moderna é, precisamente, a subordinação de todos os outros valores a esse. Embora, de certa forma, ainda aspire a valores aristocráticos, títulos de nobreza, honra e estima - valores tipicamente medievais - o conquistador tem plena consciência de que tudo pode ser obtido através do dinheiro, tanto valores materiais, como também espirituais. "A causa pela qual os espanhóis destruíram tal infinidade de almas foi unicamente não terem outra finalidade última senão o ouro, para enriquecer em pouco tempo". ${ }^{5}$

Outro elemento importante para compreender a barbaridade que dominava os espanhóis, ainda segundo Todorov, é o "prazer intrínseco na crueldade, no fato de exercer poder sobre os outros, na demonstração de sua capacidade de dar a morte". ${ }^{6}$ Os seres humanos demonstram sua crueldade intrínseca sempre que há uma fragilidade de laços sociais e uma desestruturação valorativa. ${ }^{7}$ Isto é, quando não há leis, regras e, enfim, uma estrutura social e moral capaz de estabelecer limites. "Afastados de todo temor de Deus e do rei, [os espanhóis] esqueceram também que eram homens". ${ }^{8}$ As colônias, assim, eram terras sem lei, onde os fins últimos de obter ouro e propagar a fé cristã justificavam toda e qualquer ação-meio para atingi-los.

Se o assassinato religioso foi um sacrifício, o massacre foi um assassinato ateu, inventado ou reinventado pelos espanhóis. As fogueiras da inquisição parecem-se mais com os sacrifícios. Certamente, os massacres são uma marca registrada da modernidade: 'A barbárie dos espanhóis nada tem de atávico, ou de animal, é bem humana e anuncia a chegada dos tempos modernos'. 9

4 Ibid., p. 138.

${ }^{5}$ LAS CASAS, B. op. cit., p. 27.

${ }^{6}$ TODOROV, T. op. cit., p. 138-139.

${ }^{7}$ Nietzsche, com razão, já havia dito: "ver-sofrer faz bem, fazer-sofrer mais bem ainda - eis uma frase dura, mas um velho e sólido axioma humano, demasiado humano [...] sem crueldade não há festa: é o que ensina a mais antiga e mais longa história do homem - e no castigo também há muito de festivo!". Cf. NIETZSCHE, Friedrich. Genealogia da moral: uma polêmica. São Paulo: Companhia das Letras, 1998, p. 56.

${ }^{8}$ LAS CASAS, B. op. cit., p. 95.

9 SILVA FILHO, José Carlos Moreira. Da 'invasão' da América aos sistemas penais de hoje: o discurso da 'inferioridade' latino-americana. In: WOLKMER, Antônio Carlos (org.). Fundamentos de história do direito. $2^{\underline{a}}$ ed. Belo Horizonte: Del Rey, 2003, p. 291. 
Além da violência física, outros mecanismos foram utilizados para subjugar as populações indígenas. Dentre estes, pode-se mencionar: a aculturação pela conversão forçada à fé cristã e aos hábitos europeus, a queima de livros e a destruição de objetos, templos e ídolos da cultura indígena ${ }^{10}$, bem como a constante renomeação, com signos espanhóis, das terras e locais "descobertos". Cristóvão Colombo, por exemplo, relata em seus diários de navegação seu gosto por atribuir nomes "justos" aos locais por onde passava. ${ }^{11}$

Como se observa, os espanhóis chegaram à América certos da superioridade de sua civilização e dos seus valores. Os outros eram bárbaros, pagãos. Canibais, que não conheciam a escrita, a tração animal, nem, é claro, o único e verdadeiro Deus. Realizavam cultos estranhos - muitas vezes, com sacrifícios - a deuses desconhecidos. Por fim, falavam outra língua, tornando ainda mais incompreensíveis seus hábitos, costumes e crenças.

Eis uma característica, incipiente na época, mas que se intensificará no decorrer da era moderna: o desrespeito às diferenças e à cultura dos outros povos. De fato, a modernidade é marcada por um intenso processo de homogeneização das identidades culturais, de silenciamento de saberes e práticas sociais alternativas e, enfim, de naturalização das relações de poder através da imposição de discursos e verdades supostamente únicos e universais. A imposição de dogmas religiosos e, hoje, acrescentaríamos, científicos - como forma de dominar e subjugar povos estranhos é, com certeza, algo ainda marcante na nossa época.

Como será analisado adiante, os acirrados debates em torno da legitimidade da conquista - de um lado, aqueles que buscavam justificativas para a opressão espanhola e, de outro, aqueles que lutavam pela autodeterminação dos povos nativos - levantam questões ainda presentes na nossa realidade. Antes, contudo, serão enfatizados alguns aspectos da legislação colonial espanhola.

\footnotetext{
10 "Cortez [conquistador espanhol] conta: 'Fiz com que fossem tirados de seus lugares e jogados pelas escadarias os ídolos mais importantes, em que eles acreditavam mais; fiz com que limpassem as capelas onde se encontravam, pois estavam cheias do sangue dos sacrifícios e nelas pus as imagens de Nossa Senhora e de outros santos'”. Cf. Todorov, T. op. cit., p. 58.

11 TODOROV, T. op. cit, p. 27.
} 


\section{ASPECTOS JURÍDICOS DA CONQUISTA}

No período das grandes conquistas, o direito, tanto na Espanha quanto em Portugal, ainda não apresentava todas as características do que poderíamos denominar propriamente como "direito moderno". A inexistência de instituições imparciais responsáveis pelo cumprimento dos dispositivos jurídicos, a falta de sistematização das leis - as Ordenações portuguesas, por exemplo, não são códigos no sentido moderno do termo, mas mera compilação de regras e costumes anteriores, sem qualquer sistematicidade - e, por fim, a ausência de uma legitimação racional-legal a justificar a atuação estatal - Estado e Igreja se confundem no período - são peculiaridades do direito naquela época.

Manifesta-se, nesse contexto, uma reduzida autonomia do sistema jurídico colonial, ou seja, um sistema despojado de uma efetiva força simbólica e coercitiva capaz de impor suas determinações aos que se recusassem a obedecê-las. Significa dizer que os preceitos legais tiveram - e diante dos elementos mencionados, não se poderia esperar mais que isso - pouca influência na transformação direta da realidade e das relações de poder que a perpassavam.

Daí que as leis de proteção aos índios, que contrariavam interesses dos poderosos encomendeiros, tenham sido relegadas a segundo plano. Não obstante toda uma legislação determinando e estabelecendo mudanças consideráveis, os alicerces que sustentavam a estrutura social vigente mantiveram-se intactos, deixando sem peias o caminho para o massacre.

Apesar dessa ampla ineficácia, a importância do estudo das leis que, bem ou mal, regulamentaram a conquista, está no fato de representarem registros históricos de muita valia das visões de mundo e dos discursos que procuravam justificar ou condenar a conquista. De um lado, (1) encontram-se leis que autorizavam as guerras e a escravização dos ameríndios e, de outro, (2) as diversas regras protetoras dos indígenas, as quais denotam a emergência de um discurso emancipatório e libertador, ainda atual, para os povos da América Latina.

No primeiro grupo, pode-se apontar, já em 1493, a Bula Intercaetera, outorgada pelo papa Alexandre VI. A Bula, também chamada de Bula de Participação, sendo o primeiro documento "jurídico" relativo à conquista, atribuía total soberania, jurisdição e domínio à Coroa Espanhola sobre o Novo Mundo. 
Exigia-se, apenas, em contrapartida, que os Reis difundissem a fé cristã entre os povos nativos. $^{12}$

Na mesma linha, em 1514, é elaborado, por Palácio Rúbios, jurista e conselheiro dos Reis Católicos, o Requerimento. Trata-se de importante documento jurídico, que autorizava a intervenção nas colônias, bem como a declaração de guerra justa em caso de resistência. ${ }^{13}$ Justificava tal domínio recorrendo ao poder de Jesus Cristo, considerado o senhor supremo sobre todas as terras e "chefe da linhagem humana". Ele teria transferido a posse sobre o continente americano a São Pedro, que o transmitiu ao Papa, que, por sua vez, o transmitiu aos Reis Católicos, Fernando de Aragão e Isabel de Castela.

O Requerimento deveria ser lido a toda comunidade indígena prestes a ser invadida, informando-lhes a sua condição de vassalos da Coroa espanhola e garantindo, assim, a "oportunidade" de acatarem espontaneamente a dominação. A resistência por parte dos nativos, como mencionado, autorizava a guerra justa e a escravidão. ${ }^{14}$

A superioridade dos que enunciavam o Requerimento, sem dúvida, já estava contida no fato de serem eles, os espanhóis, os que falavam - numa língua incompreensível - enquanto os índios tão-somente escutavam, sendo obrigados a suportar as conseqüências da violência e da brutalidade dos conquistadores. ${ }^{15}$

É a partir do ideário consagrado nesses dois documentos jurídicos, que se criou o regime de encomendas. Trata-se de uma justificativa oficial para a escravidão dos índios. Estes eram considerados livres, mas vassalos do Rei, a quem deveriam pagar tributos. O indígena encomendado (leia-se escravo) pagava este tributo, não diretamente ao seu Senhor (o Rei), mas ao encomendeiro, pessoa que

${ }^{12}$ Cf. PIRES, Sérgio Luiz Fernandes. O aspecto jurídico da conquista da América pelos espanhóis e a inconformidade de Bartolomé de Las Casas. In: WOLKMER, Antônio Carlos (org.). Direito e justiça na América indígena: da conquista à colonização. Porto Alegre: Livraria do Advogado, 1998, p. 64.

${ }^{13}$ WOLKMER, Antônio Carlos. Humanismo e cultura jurídica latino-americana. In: WOLKMER, A. C. Humanismo e cultura jurídica no Brasil. Florianópolis: Fundação Boiteux, 2003, p. 26.

14 Bastante representativo é o seguinte trecho do Requerimento: "Se não o fizerdes [isto é, se não acatarem a fé cristã voluntariamente], ou se demorardes maliciosamente para tomar uma decisão, vos garanto que, com a ajuda de Deus, invadir-vos-ei poderosamente e far-vos-ei a guerra de todos os lados e de todos os modos que puder, e sujeitar-vos-ei ao jugo e à obediência da Igreja e de Suas Altezas. Tomarei vossos bens e far-vos-ei todo o mal, todo o dano que puder, como convém a vassalos que não obedecem a seu senhor, não querem recebê-lo, resistem a ele e o contradizem" Cf. TODOROV, T., op. cit., p. 144.

15 lbid., p. 145. 
usufruía desse benefício, isto é, do trabalho indígena, como recompensa dos serviços prestados à Coroa. ${ }^{16}$

Segundo a ideologia do colonizador, desse modo, a encomenda não implicava em propriedade sobre os índios, que seriam vassalos livres, nem sobre suas terras. Implicava apenas em usufruto de seu trabalho, obtido por produto de suas terras ou das propriedades dos encomendeiros.

Contra esse discurso oficial, consagrado no regime de encomendas e nos textos jurídicos e religiosos citados, insurgiram-se uma série de teólogos e pensadores da época, dentre os quais se destaca o frei dominicano Bartolomé de Las Casas, um dos principais responsáveis pela promulgação do segundo grupo de leis mencionado acima, isto é, as leis de proteção aos índios.

Dentre estas, destacam-se a Lei de Burgos, promulgada em 1512, e as Leis Novas, de 1542. A Lei de Burgos, composta de trinta e cinco artigos, demonstrava uma nítida preocupação do Estado espanhol em cumprir as promessas de evangelização dos ameríndios. Com esse intuito, garantia-lhes o direito a bons tratos, à alimentação adequada e, ainda, ao pagamento de um salário. A evangelização dos índios e a instrução dos filhos dos caciques foram estabelecidas como tarefas obrigatórias para o encomendeiro. ${ }^{17}$ As Leis Novas, por sua vez, fruto direto da atuação de Las Casas, "destinavam-se a proteger a vida dos índios", tendo "o claro propósito de frear o ímpeto demolidor e individualista dos conquistadores". ${ }^{18}$ As suas principais determinações foram a proibição de novas conquistas e o confisco de encomendas então existentes.

Ocorre que tais leis não foram efetivadas. A forte resistência por parte dos encomendeiros, inclusive com a realização de motins, pode ser apontada como a principal causa. Em termos jurídicos, criou-se um instituto que permitia que, em havendo razões justificadoras, as leis da Coroa não fossem cumpridas na colônia: "Se acata, pero no se cumple", diziam os conquistadores. Com base nesse dispositivo, a autoridade colonial podia suspender o cumprimento da lei da Coroa,

${ }^{16}$ Sobre o regime de encomendas, ver PIRES, S. L. F. op. cit., p. 67; e BRUIT, H. H. op. cit., p. 21-31. Este último aponta algumas peculiaridades que o regime assumiu nas diversas colônias espanholas.

${ }^{17}$ Para mais detalhes sobre a Lei de Burgos, cf. BRUIT, H. H. op. cit, p. 27-28.

18 Ibid., p. 29. 
cabendo ao Rei homologar o feito ou, ao contrário, determinar - o que dificilmente acontecia - o seu imediato cumprimento. ${ }^{19}$

A tensão entre o ideário presente nos dois grupos de leis - em especial, 0 Requerimento e as Leis Novas - representa os interesses das duas forças que se confrontaram no decorrer da conquista. De um lado, os que defendiam a guerra justa e o submetimento dos povos autóctones e, de outro, aqueles que batalharam pela proteção e afirmação desses povos. É o que veremos, com mais detalhe, no tópico seguinte.

\section{O DEBATE ENTRE BARTOLOMÉ DE LAS CASAS E JUAN GINÉS SEPÚLVEDA}

Nascido em Sevilha, em 1484, Bartolomé de Las Casas veio para a América, pela primeira vez, em 1502, em companhia do governador Nicolas de Ovando, a fim de tornar-se encomendeiro. E assim o fez até 1514, quando passou pela "primeira conversão", três anos após ouvir o sermão - intitulado Sou uma voz que clama no deserto - do padre dominicano Antônio de Montesinos, na llha Espanhola (São Domingos). Montesinos alertava aos seus compatriotas que teriam que responder perante Deus pelos pecados realizados no Novo Mundo, particularmente, no que concerne aos maus-tratos prestados aos indígenas. ${ }^{20}$

Nesta época, Las Casas residia em Cuba, onde presenciou a sangrenta conquista da ilha, comandada por Diego Velásquez e Panfilo de Narváez, onde foram assassinados aproximadamente sete mil índios. A partir de então, abrindo mão de suas posses e encomendas, até o fim da vida, lutou incansavelmente em prol dos ameríndios. ${ }^{21}$

Com o apoio da Coroa, angariou recursos para formar uma redução indígena, em 1520, na Conumá (Venezuela). A redução era a única forma por ele

\footnotetext{
${ }^{19}$ PIRES, S. L. F. op. cit., p. 68.
}

20 "Com que direitos haveis desencadeado uma guerra atroz contra essas gentes que viviam pacificamente em seu próprio país? Por que os deixais em semelhante estado de extenuação? Os matais a exigir que vos tragam diariamente seu ouro. Acaso não são eles homens? Acaso não possuem razão, e alma? Não é vossa obrigação amá-los como a vós próprios? Podeis estar certos que, nessas condições, não tereis maiores possibilidades de salvação do que um mouro ou um turco...”, dizia Montesinos. Cf. BUEENO, Eduardo. Genocídio de ontem e hoje. In: LAS CASAS, Bartolomé de. op. cit., p. 12-13. 
entendida de levar o evangelho aos indígenas sem submetê-los ao regime de exploração. Entretanto, o projeto fracassou em 1522, mesmo ano em que ingressou na Ordem dos Dominicanos.

Em 1542, obteve uma de suas maiores vitórias. Trata-se da publicação, pelo Rei Carlos, das Leis Novas, que, conforme mencionado, extinguiam o regime de encomendas e proibiam novas conquistas. Segundo Lorenzo Galmés, "é indubitável a grande satisfação de Las Casas e a influência que ele exerceu [...]. Mas não podemos esquecer que ele esperava mais, queria soluções mais radicais". ${ }^{22}$

Em 1543, Las Casas foi nomeado Bispo de Chiapas, tomando posse em 1545. No ano seguinte, abandonou a diocese em face da constante afronta política dos poderosos encomendeiros e da recusa de uma junta eclesiástica da região em referendar seus entendimentos.

Retornou à Espanha, onde passou a trabalhar na confecção de sua vasta obra escrita. A palavra - consubstanciada nos relatos dos massacres e nas denúncias de abuso de poder por parte dos encomendeiros - era o principal instrumento utilizado pelo frade na sua luta em prol dos índios. A partir dos seus escritos criou-se a chamada legenda negra, rótulo através do qual se propagou por todo o mundo europeu "a imagem dos espanhóis como um povo sanguinário, cruel e corrupto: analfabetos truculentos que se lançaram sobre o Novo Mundo como aves de rapina". ${ }^{23}$

Em 1550, diante das intensas discussões políticas, religiosas e jurídicas em torno da conquista, das quais Las Casas era um dos mais conhecidos propagadores, o Rei Carlos I ordenou a suspensão dos empreendimentos coloniais a fim de que os pontos controvertidos fossem investigados e decididos por uma junta de especialistas. ${ }^{24}$

${ }^{21}$ Dados biográficos de Las Casas podem ser encontrados nos trabalhos de BRUIT, H. H. op. cit, p. 5963; BUENO, Eduardo. op. cit., p. 09-23; GALMÉS, Lorenzo. Bartolomeu de Las Casas: defensor dos direitos humanos. São Paulo: Paulinas, 1991.

22 GALMÉS, L. op. cit., p. 141.

${ }^{23}$ BUENO, E. op. cit., p. 11.

24 GALMÉS, L. op. cit., p. 185-186. A polêmica de Valladolid resumia-se, basicamente, a duas dúvidas: "uma de fato, colocada pela seguinte questão: eram os índios tão bárbaros e inferiores ao ponto de ser necessária a guerra para tirá-los desse estado? A outra questão era de direito: era justa, em si, a guerra contra os índios como meio de propagar o cristianismo na América?" Cf. BRUIT, H. H., op. cit, p. 122. 
Com esse intuito, então, foi organizado um debate entre dois importantes teólogos espanhóis da época: Bartolomé de Las Casas e Juan Ginés Sepúlveda. Trata-se da famosa controvérsia de Valladolid, realizada em duas sessões, entre agosto e setembro de 1550 e maio de 1551. Catorze juízes - dentre eles, teólogos, letrados e juristas - integraram a comissão encarregada de avaliar os argumentos dos contendores. ${ }^{25}$

Opuseram-se naquele evento as duas teses centrais que marcaram as discussões sobre a justiça ou injustiça da colonização. Na primeira delas, encontram-se aqueles que sustentavam que o domínio europeu, fundado na autoridade do Papa e do Rei, justificava-se em face da superioridade da sua civilização diante dos valores bárbaros dos índios. Estes, acaso resistissem à dominação espanhola, poderiam ser subjugados por intermédio da guerra justa.

De outro lado, situam-se aqueles teólogos (Francisco de Vitória, Domingos de Soto) e religiosos dominicanos (Montesinos, Las Casas), que, amparados no direito natural, entendiam "não ser correto colocar a jurisdição dos colonizadores para além de suas fronteiras", de maneira que "os indígenas, ainda que gentios, possuíam dignidade e direitos humanos. Esses doutrinadores não reconheciam o poder do Papa e a pretensa jurisdição universal dos monarcas sobre os infiéis" . ${ }^{26}$

Em defesa da primeira tese, Juan Ginés Sepúlveda reconhecia a desigualdade - e não a igualdade - como o estado natural da sociedade humana. Segundo o autor, as relações sociais são marcadas por traços de hierarquia, de forma que os senhores sempre mandam nos servos. Da mesma forma ocorre nas relações entre os animais e as coisas da natureza, onde, respectivamente, os fortes dominam os fracos e as formas perfeitas prevalecem diante das imperfeitas. Daí a conclusão de que:

A esta lei estão submetidos os homens e os animais. Por isso, as feras se amansam e sujeitam-se ao império do homem. Por isso, o varão impera sobre a mulher, o homem adulto sobre a criança, o pai sobre seus filhos, quer dizer, os mais poderosos e mais

${ }^{25}$ BRUIT, H. H. op. cit, p. 121.

${ }^{26}$ WOLKMER, Antônio Carlos. Pluralidade jurídica na América luso-hispânica. In: Wolkmer, A. C. (org.). Direito e justiça na América indígena: da conquista à colonização. Porto Alegre: Livraria do Advogado, 1998, p. 84. 
perfeitos sobre os mais débeis e imperfeitos. Isso mesmo se verifica entre os homens; alguns, por natureza, são senhores, outros, por natureza, são servos. ${ }^{27}$

Portanto, sendo certo que os índios eram povos bárbaros - ou seja, que não têm fé, leis, sacrificam e se alimentam de vítimas humanas em cultos satânicos inferiores aos espanhóis, nada mais justo e conforme a natureza que estes os dominassem. Além disso, os conquistadores poderiam recorrer à violência a fim de impor a dominação, pois a conquista era vista como um ato de justiça, capaz de retirar o bárbaro da sua barbárie, oferecendo-lhe todas as benesses da vida civilizada. ${ }^{28}$

O seguinte trecho sintetiza os argumentos de Juan Ginés Sepúlveda:

É justo e útil que [os índios] sejam servos, e vemos que isso é sancionado pela própria lei divina, pois está escrito no livro dos provérbios: 'o tolo servirá aos sábios'. Assim são as nações bárbaras e desumanas, estranhas à vida civil e aos costumes pacíficos. E sempre será justo e de acordo com o direito natural que essas pessoas sejam submetidas ao império de príncipes e de nações mais cultivadas e humanas, de modo que graças à virtude dos últimos e à prudência de suas leis, eles abandonam a barbárie e se adaptam a uma vida mais humana e ao culto da virtude. E se recusam esse império, é permissível impô-lo por meio das armas e tal guerra será justa, assim como declara o direito natural [...]. Concluindo: é justo, normal e de acordo com a lei natural que todos os homens probos, inteligentes, virtuosos e humanos dominem todos os que não possuem essas virtudes. ${ }^{29}$

Contrapondo-se aos argumentos de Sepúlveda, Las Casas, em seu primeiro pronunciamento, falou durante cinco dias. Isso demonstra a densidade das teses do frade dominicano, sua intensa preparação para o debate e a importância dada ao evento. $^{30}$

É importante ressaltar, de início, que Las Casas, ao longo da vida, adotou uma postura assimilacionista, no sentido de que não se opunha à colonização em si, mas apenas aos métodos violentos utilizados. A alternativa proposta visava tãosomente à substituição da conquista violenta - realizada por meio dos assassinatos e da matança generalizada - por uma outra forma mais humana e, por conseguinte,

${ }^{27}$ Citado por BRUIT, H. H. op. cit., p. 127.

${ }^{28}$ SILVA FILHO, J. C. M. op. cit., p. 297.

${ }^{29}$ Citado por PIRES, S. op. cit., p. 70.

${ }^{30}$ Segundo BRUIT, H. H., op. cit., p. 122, Las Casas "foi para o debate disposto não só a convencer o tribunal, mas para arrasar com seu contendor". 
mais eficaz na conversão dos índios à fé cristã. Daí, por exemplo, as experiências de Las Casas em torno das reduções indígenas. ${ }^{31}$ A respeito dessa fase de Las Casas, Tzevtan Todorov menciona que

[...] pedindo uma atitude mais humana em relação aos índios [os religiosos] fazem a única coisa possível, e realmente útil; se alguém contribuiu para melhorar a situação dos índios esse alguém foi Las Casas; o ódio inextinguível que sentiam por ele todos os adversários dos índios, todos os defensores da superioridade branca, comprova-o suficientemente. ${ }^{32}$

No debate com Sepúlveda, contudo, Las Casas apresentou teses mais radicais $^{33}$, o chamado perspectivismo: cada um adora Deus à sua maneira, da forma que pode. E oferecer a vida, o que há de mais precioso, tal como fazem os índios em relação aos seus deuses, é a maior prova de amor que se pode dar a Ele.

Partindo desse pressuposto, Las Casas apontou a necessidade de reconhecer as diferenças e, aliado a isso, a dignidade dos índios. Estes não podiam ser subjugados contra a sua vontade, uma vez que não eram súditos da Igreja e, muito menos, do Rei espanhol. Eram, na verdade, súditos em potencial, que poderiam um dia consentir no domínio espanhol e acatar a fé católica. Enquanto isso não ocorresse, qualquer guerra contra os ameríndios seria injusta.

Las Casas, seguindo a perspectiva mencionada, desconstruiu a argumentação de Sepúlveda de que os índios eram povos bárbaros. Para tanto, relativizou o conceito, demonstrando que, sob a ótica dos ameríndios, os espanhóis também eram bárbaros, na medida em que falavam uma língua ininteligível e, o que é pior, cometiam atrocidades e crueldades de toda espécie contra os habitantes do Novo Mundo. Foram tais atrocidades, acrescenta Las Casas, que puseram a organização social dos indígenas em desordem, sendo um equívoco apontar que, desde sempre, conforme sua natureza, os índios viveriam nesse estado.

Nas palavras do frade dominicano:

Deste modo, estas gentes das Índias, que nós estimamos como bárbaros, consideram-nos, também, como bárbaros, pois não nos entendem e lhes somos estranhos. [...] podemos afirmar que eles, com reta razão, por ver em nós outros costumes, estimam-nos não apenas

\footnotetext{
${ }^{31}$ É o que se pode chamar de "experiências de colonização pacífica". Cf. GALMÉS, L., op. cit., p. 89-97. 32 TODOROV, T. op. cit., p. 169.
} 
como bárbaros da segunda espécie, que quer dizer estranhos, senão da primeira, isto é, ferocíssimos, duríssimos, aspérrimos e abomináveis. ${ }^{34}$

Las Casas também rebateu o argumento de que os índios seriam bárbaros porque sacrificavam e se alimentavam de vítimas em cultos satânicos. Em primeiro lugar, reconheceu que, em si mesmos, os sacrifícios humanos são condenáveis, mas não decorre daí nenhum direito dos espanhóis - que, aliás, podemos acrescentar, na Europa queimavam homens e mulheres nas fogueiras da Inquisição - em "declarar guerra àqueles que os praticam: o remédio corre então o risco de ser pior que o mal" ${ }^{35}$

O frade dominicano ressaltou, em seguida, que os sacrifícios não são estranhos à tradição cristã, como demonstram os casos de Abraão e Isaac e, especialmente, de Jesus Cristo. Lembrou, ainda, que os próprios espanhóis, impelidos pela necessidade, tinham comido carne humana em alguns momentos. Ademais, nas guerras justas foram mortos muito mais índios pelos espanhóis do que teriam morrido nos sacrifícios aos deuses indígenas. Por fim, além de razões históricas, o sacrifício humano é aceitável na medida em que cada um adora Deus à sua maneira - mesmo que não seja o verdadeiro Deus. Dar a vida por Ele é o que há de mais precioso e intenso na devoção, de forma que o sacrifício teria origem na lei natural. ${ }^{36}$ Conclui Las Casas:

As nações que ofereciam sacrifícios humanos a seus deuses mostravam assim [...] a alta idéia que tinham da excelência da divindade, do valor dos deuses, o quanto era nobre, e grande sua veneração pela divindade. Demonstraram, conseqüentemente, que possuíam, mais do que as outras nações, a reflexão natural, a retidão da palavra e o julgamento da razão [...]. E em religiosidade superaram todas as outras nações, pois são as nações mais religiosas do mundo que, para o bem de seus povos, oferecem em sacrifício seus próprios filhos. ${ }^{37}$

33 "[...] pode-se tomar o ano do debate de Valladolid, 1550, como ponto de referência [...]. A atitude de Las Casas em relação aos índios, o amor que sente por eles, não são os mesmos antes e depois dessa data". Cf. TODOROV, T. op. cit., p. 184 e 186-187.

\footnotetext{
${ }^{34}$ Citado por BRUIT, H. H. op. cit., p. 129.

${ }^{35}$ TODOROV, T. op. cit., p. 186.

36 Ibid. op. cit., p. 187; BRUIT, H. H., op. cit., p. 134.

${ }^{37}$ Citado por TODOROV, T., op. cit., p. 188.
} 
O caráter relativo do conceito de bárbaro, a impossibilidade de uma guerra justa, as limitações ao poder da Igreja e ao poder real, que somente podem se legitimar pelo consentimento dos súditos, bem como a necessidade de respeitar os costumes indígenas, mesmo que contrariassem dogmas cristãos, revelam o traço emancipatório e radical do discurso de Las Casas. O perspectivismo, por ele elaborado, aponta, já em 1550, para a importância do diálogo com a diferença e da busca pela compreensão do outro.

Daí que, coerente com suas premissas, Las Casas tenha chegado a sugerir que o Rei da Espanha renunciasse ao domínio sobre a América indígena, devolvendo aos índios a liberdade e a soberania sobre suas terras. A única guerra legítima, nesse contexto, seria da Coroa contra os próprios conquistadores espanhóis, no caso destes não se retirarem pacificamente. Las Casas, enfim, defende que os índios deveriam, autonomamente, escolher seu futuro. ${ }^{38}$

Os debates de Valladolid não culminaram numa decisão formal em favor de uma das partes, pois os teólogos que os presidiram, Domingo de Soto, Melchor Cano e Bartolomeu de Carranza, julgaram-se impotentes para proferir um veredicto definitivo.

Las Casas morreu aos oitenta e dois anos de idade, em 1566, deixando a marca da unidade de sua vida, e da sua obra. Nas palavras de Wolkmer, Las Casas "transcende a historicidade de seu tempo, tornando-se o paladino de uma ética libertária não só de base indígena, mas de dimensão adequada a todos os povos oprimidos da América" ${ }^{39}$

O debate entre Sepúlveda e Las Casas, é certo, envolve questões que atravessam toda a modernidade. De um lado, o etnocentrismo, a imposição de verdades universais e a intolerância diante dos valores do outro, tal como enunciado pelo primeiro autor. De outro, a defesa intransigente, por parte de Las Casas, da autodeterminação dos povos e do respeito à diversidade.

Sem hesitar, pode-se reconhecer naquele confronto de idéias e práticas sociais, ocorrido em meados do século $\mathrm{XVI}$, o prenúncio de problemas que, ainda hoje, restam irresolutos. Mais que isso, as críticas e denúncias de Bartolomé de Las Casas revelam, com clareza, o "nascimento de uma sociedade corroída em seus

$$
38 \text { Ibid., p. } 191 .
$$


próprios fundamentos, desequilibrada, perpetuamente condenada à injustiça”. ${ }^{40} \mathrm{Não}$ há contradição alguma, nesse sentido, em dizer que a época das luzes foi marcada por muito mais trevas do que qualquer período anterior da história humana...

\section{CONCLUSÃO}

O amálgama entre mercantilismo e religião - capitalismo e fundamentalismo, diríamos hoje - é uma das características fundantes da conquista espanhola. Em nome de Deus e do ouro, foram cometidas atrocidades inimagináveis, sendo mortos mais de 70 milhões de seres humanos.

Hodiernamente, deparamo-nos com uma situação similar. Ao que parece, a perda de referenciais éticos, morais ou jurídicos chegou a tal ponto que o discurso imperialista oficial sequer se preocupa em defender a veracidade das justificativas utilizadas para seus atos.

Emerge, nesse contexto, o antigo e renitente discurso da negação do outro e do desrespeito à diversidade. Em nome de Deus e da "liberdade" territórios nacionais são invadidos, povos são subjugados e pessoas morrem todos os dias. Assim como os índios sofreram (e ainda sofrem) na pele esse amálgama, os iraquianos, afegãos, palestinos, dentre outros, vivem hoje as misérias de uma guerra sem sentido.

Tem razão o romancista português, José Saramago, quando afirma que

[...] de algo sempre haveremos de morrer, mas já se perdeu a conta aos seres humanos mortos das piores maneiras que seres humanos foram capazes de inventar. Uma delas, a mais criminosa, a mais absurda, a que mais ofende a simples razão, é aquela que, desde o princípio dos tempos e das civilizações, tem mandado matar em nome de Deus. ${ }^{41}$

Num tempo em que as ordens de Deus se confundem com os ditames do mercado, e no qual a resignação é colocada como única alternativa, parece importante resgatar os ensinamentos de Bartolomé de Las Casas. A coragem de quem abandonou a acomodação de uma vida com muitas posses e escravos para se dedicar, até seus últimos dias, à concretização da utopia de uma sociedade mais

\footnotetext{
${ }^{39}$ WOLKMER, A. C., op. cit., 1998, p. 85.

${ }^{40}$ BRUIT, H. H. op. cit., p. 58.

${ }^{41}$ SARAMAGO, José. O fator deus. Folha de São Paulo, 19 de setembro de 2001.
} 
justa e plural, bem como o recurso às palavras e aos discursos críticos como principal arma, é, sem dúvida, algo que hoje nos falta.

\section{REFERÊNCIAS}

BRUIT, Héctor Hernan. Bartolomé de Las Casas e a simulação dos vencidos. Campinas: Unicamp, 1995.

BUENO, Eduardo. Genocídio de ontem e hoje. In: LAS CASAS, Bartolomé de. O paraíso destruído: brevíssima relação da destruição das Índias. 6ª ed. Porto Alegre: L\&PM, 1996, p. 09-23.

GALMÉS, Lorenzo. Bartolomeu de Las Casas: defensor dos direitos humanos. São Paulo: Paulinas, 1991.

LAS CASAS, Bartolomé de. O paraíso destruído: brevíssima relação da destruição das Índias. $6^{\underline{a}}$ ed. Porto Alegre: L\&PM, 1996.

LEÓN-PORTILLA, Miguel. A visão dos vencidos: a tragédia da conquista narrada pelos astecas. Tradução: Carlos Urbin e Jacques Wainberg. Porto Alegre: L\&PM, 1985.

NIETZSCHE, Friedrich. Genealogia da moral: uma polêmica. Tradução: Paulo César de Souza. São Paulo: Companhia das Letras, 1998.

PIRES, Sérgio Luiz Fernandes. O aspecto jurídico da conquista da América pelos espanhóis e a inconformidade de Bartolomé de Las Casas. In: WOLKMER, Antônio Carlos (org.). Direito e justiça na América indígena: da conquista à colonização. Porto Alegre: Livraria do Advogado, 1998, p. 55-74.

SILVA FILHO, José Carlos Moreira. Da 'invasão' da América aos sistemas penais de hoje: o discurso da 'inferioridade' latino-americana. In: WOLKMER, Antônio Carlos (org.). Fundamentos de história do direito. $2^{\mathrm{a}}$ ed. Belo Horizonte: Del Rey, 2003, p. 279-329

SARAMAGO, José. O fator deus. Folha de São Paulo, 19 de setembro de 2001.

TODOROV, Tzvetan. A conquista da América: a questão do outro. $2^{\underline{a}}$ ed. São Paulo: Martins Fontes, 1988.

WOLKMER, Antônio Carlos. Humanismo e cultura jurídica latino-americana. In: Wolkmer, A. C. Humanismo e cultura jurídica no Brasil. Florianópolis, Fundação Boiteux, 2003, p. 19-40.

Pluralidade jurídica na América luso-hispânica. In: Wolkmer, A. C. (org.). Direito e justiça na América indígena: da conquista à colonização. Porto Alegre: Livraria do Advogado, 1998. 